UDC 338.1

JEL O34

DOI 10.25205/2542-0429-2019-19-1-133-140

\title{
A New Holistic Approach \\ for Studying Blockchain-Based Intellectual Property Rights Ecosystem
}

\author{
I. Alnafrah, E. L. Bogdanova \\ ITMO University \\ St. Petersburg, Russian Federation
}

Abstract

This study aims at proposing and analysing a new holistic approach for studying Blockchain-based intellectual property rights (IPRs) ecosystem, since Blockchain technology has a potential to revolutionize the conventional intellectual property rights system and overcome problems of this system associated with rights protection, securing trade secrets, claiming copyrights, proving prior use, and data availability.

In this study documentary research method (DSM) is used to build a comprehensive framework including all possible components and stakeholders in the intellectual property rights system. This framework illustrates the workflow scheme of a Blockchain-based IPRs platform.

The introduced approach in this study consists of several steps, beginning with identifying stakeholders and ending with designing the mechanism by which the Blockchain-based IPRs platform works.

This study introduces this new approach in order to draw roadmap for deploying Blockchain technology in the current intellectual property rights system. Moreover, this study provides policy makers with procedural details guiding them to make optimal policies related to using this new technology.

Keywords

Blockchain Technology, Intellectual Property Rights, IPRs System, Blockchain-based IPRs Platform, Proof of Work, Proof of Stake

For citation

Alnafrah I., Bogdanova E. L. A New Holistic Approach for Studying Blockchain-Based Intellectual Property Rights Ecosystem. World of Economics and Management, 2019, vol. 19, no. 1, p. 133-140. DOI 10.25205/2542-0429-201919-1-133-140

\section{Новый целостный подход \\ к изучению экосистемы прав интеллектуальной собственности, основанной на использовании технологии блокчейн}

\author{
И. Альнафра, Е. Л. Богданова \\ Санкт-Петербургский национальный исследовательский \\ университет информационных технологий, механики и оптики \\ Санкт-Петербург, Россия
}

\section{Аннотаиия}

Исследование направлено на предложение и анализ нового целостного подхода к изучению экосистемы прав интеллектуальной собственности (ПИС), основанной на использовании технологии блокчейн, поскольку эта технология способна революционизировать традиционную систему прав интеллектуальной собственности и преодолеть проблемы этой системы, связанные с защитой прав, сохранением коммерческой тайны, заявлением об авторских правах, доказательством предварительного использования и доступности данных.

В этом исследовании метод документального исследования (МДИ) используется для создания всеобъемлющей структуры, включающей все возможные компоненты и заинтересованные стороны в системе прав интел- 
лектуальной собственности. Эта структура иллюстрирует схему рабочего процесса платформы ПИС, основанной на использовании технологии блокчейн.

Представленный в этом исследовании подход состоит из нескольких этапов, начиная с определения заинтересованных сторон и заканчивая разработкой механизма, с помощью которого работает платформа ПИС, основанная на использовании технологии блокчейн.

Представлен новый подход для составления плана развертывания технологии блокчейн в существующей системе прав интеллектуальной собственности. Кроме того, это исследование предоставляет органам государственной власти процедурные детали, которые помогут им разработать оптимальную политику, связанную с использованием этой новой технологии в сфере защиты и управления интеллектуалкой собственности.

Ключевые слова

технология блокчейн, права интеллектуальной собственности, система прав интеллектуальной собственности, платформа прав интеллектуальной собственности, основная на технологии блокчейн, доказательство работы, доказательство ставки.

\section{Introduction}

Protection of intellectual property rights (IPRs) is considered a crucial issue at the national level influencing the intensity of innovation activities and plays an important role in creating motivation for entrepreneurs to innovate and invent as well $[5 ; 15]$. However, the current intellectual property rights system requires a considerable time, costs, and efforts to protect these rights. Moreover, this conventional system does not cover effectively some IPRs system problems such as, claiming copyrights [14], securing trade secrets [6], protecting patents [3], and most importantly intellectual property data availability [10].

Additionally, the current IPRs system suffers from various shortcomings in terms of time required for patenting, weak evidence of ownership and prior of exacting for legal litigations, and the complexity of conducting patent landscape of a specific technology.

Accordingly, deploying Blockchain technology in the current IPRs system has a real potential to overcome all these shortcomings. Using such technology becomes a vital instrument enhancing the productivity and functionality of the IPRs management system. Using this technology to manage patent system, for example, will speed up patenting process that takes, in the current system, 3-5 years to fill patent application and examine the patentability of invention [17]. Additionally, Blockchain-based IPRs platform also will cut the cost needed for legal procedures and litigations.

In this article, we argue that deploying Blockchain technology within the IPRs system overcomes all previous problems of the current IPRs system. Moreover, it creates a marketplace for inventors, investors and policy makers to interact with each other efficiently and consequently improves the innovation activities at the national.

These objectives can be achieved by creating a Blockchain-based IPRs platform protecting IPRs, providing immutable proof of existing and proof of ownership, and creating a functioning marketplace.

\section{Literature review}

Blockchain technology was introduced in a systemic form by Satoshi Nakamoto in 2008, when he published his white paper [13] about "Peer-to-Peer electronic cash system". This new system uses blockchain technology as tool to build a distributed network. The blockchain technology is "a distributed ledger representing a network consensus of every transaction that has ever occurred." [16]. This new technology creates a network, where each participant has a copy of the ledger, where no one can change the information of transactions within this network. It can be said that this technology stores the information of all transactions on the network in an immutable way by using hash function. 
Each participant represents a nod on the blockchain network and each one has two keys: (1) public cryptographic key and (2) private cryptographic key. These keys are used to conduct transactions among all participants without intervention from any third party.

Generally speaking, each block in the blockchain consists of following elements:

- Header

- The hash value of the previous block

- The current block hash value

- Transaction information

- A timestamp

- Nonce

Figure 1 represents blockchain network structure.

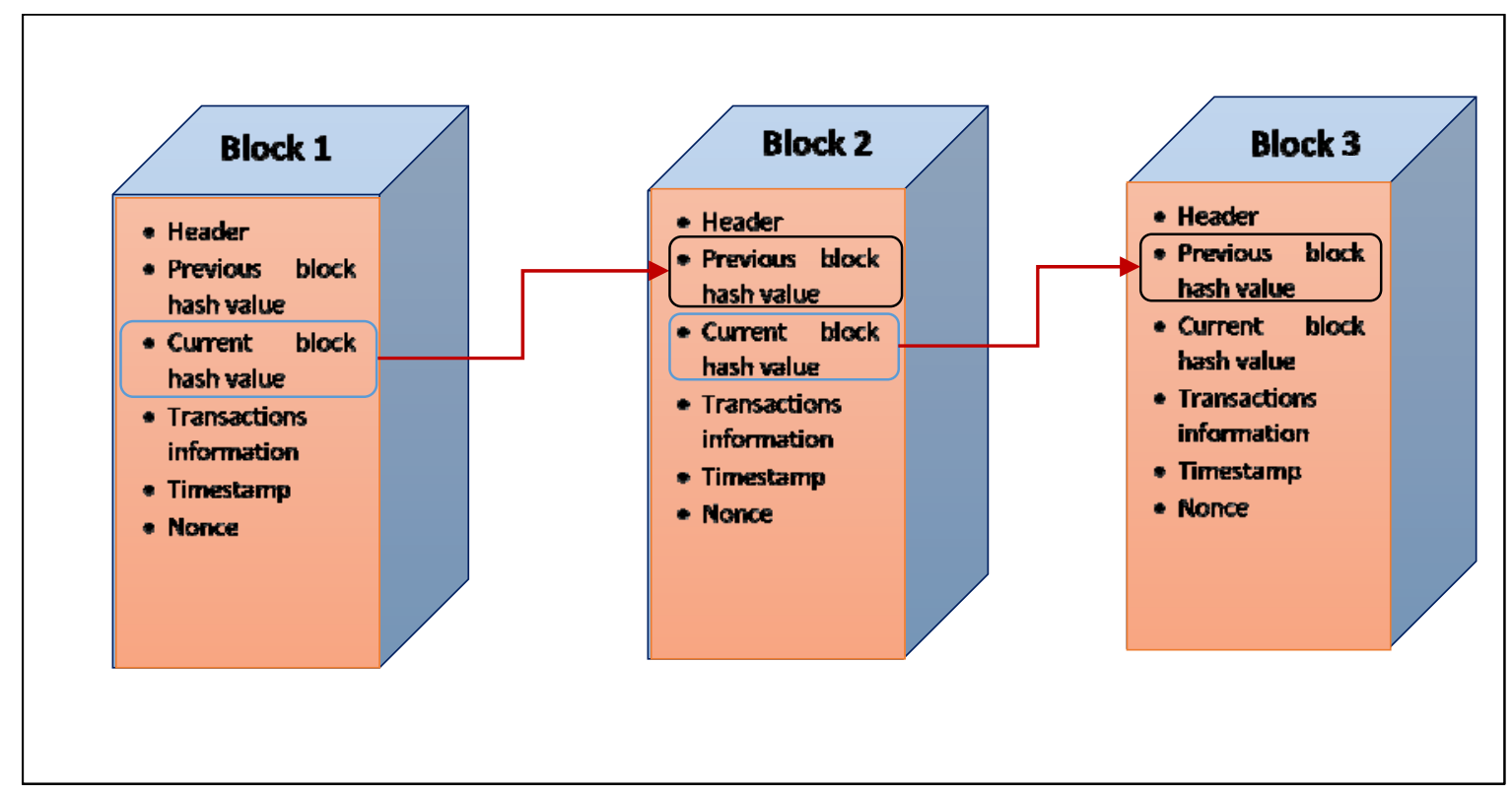

Fig. 1. Blockchain structure

Blockchain technology makes it very difficult to change the information within the network. There is only one possible way to change and control the blockchain network. It is when more $51 \%$ of the hashes are controlled by one nod or pool miners [4]. However, this situation is extremely difficult to happen, since the more participants in the blockchain network the more difficult it becomes to control the network.

Blockchain is used in various forms, where each form serves a specific objective. Accordingly, blockchain is divided into four types. This division is associated with some feature such as writing and reading access, type of ownership, speed, and type of consensus [8; 11]. In the following table we represent all possible types of blockchain networks.

As shown in the previous table, there are several types of blockchain networks. Each network serves a particular objective. Therefore, deploying blockchain technology within the IPRs system can provide numerous advantages to entrepreneurs, inventors, and policy makers. Blockchain-based IP platform will help in conducting a patent landscape of and help investors finding the right investment opportunities through enabling them explore the inventor's ideas on this platform. This platform also will help inventors to protect their idea and inventions against hackers and patent trolls. 
Types of Blockchain networks

\begin{tabular}{|c|c|c|c|c|c|c|}
\hline $\begin{array}{l}\text { Blockchain } \\
\text { form }\end{array}$ & $\begin{array}{l}\text { Writing } \\
\text { Access }\end{array}$ & $\begin{array}{l}\text { Reading } \\
\text { Access }\end{array}$ & Ownership & Speed & Consensus & Example \\
\hline $\begin{array}{l}\text { Public } \\
\text { Permissionless } \\
\text { Blockchain }\end{array}$ & $\begin{array}{l}\text { All participants } \\
\text { can write on the } \\
\text { network }\end{array}$ & $\begin{array}{l}\text { All participants } \\
\text { can read the } \\
\text { transactions } \\
\text { information on } \\
\text { the network }\end{array}$ & $\begin{array}{l}\text { There is no } \\
\text { single } \\
\text { owner of the } \\
\text { network }\end{array}$ & $\begin{array}{l}\text { Requires a } \\
\text { long time to } \\
\text { verify transac- } \\
\text { tions }\end{array}$ & $\begin{array}{l}\text { Proof of } \\
\text { work }\end{array}$ & Bitcoin \\
\hline $\begin{array}{l}\text { Public } \\
\text { Permissioned } \\
\text { Blockchain }\end{array}$ & $\begin{array}{l}\text { Only authorized } \\
\text { participants are } \\
\text { allowed to write } \\
\text { on the network }\end{array}$ & $\begin{array}{l}\text { All participants } \\
\text { can read the } \\
\text { transactions } \\
\text { information on } \\
\text { the network }\end{array}$ & $\begin{array}{l}\text { There is a } \\
\text { network } \\
\text { owner }\end{array}$ & $\begin{array}{l}\text { Faster than } \\
\text { public permis- } \\
\text { sionless } \\
\text { blockchain }\end{array}$ & $\begin{array}{l}\text { Proof of } \\
\text { work }\end{array}$ & Sovrin \\
\hline $\begin{array}{l}\text { Consortium } \\
\text { Blockchain }\end{array}$ & $\begin{array}{l}\text { Only authorized } \\
\text { participants are } \\
\text { allowed to write } \\
\text { on the network }\end{array}$ & $\begin{array}{l}\text { Only authorized } \\
\text { participants are } \\
\text { allowed to read } \\
\text { the transactions } \\
\text { information on } \\
\text { the network }\end{array}$ & $\begin{array}{l}\text { There is a } \\
\text { network } \\
\text { owner. }\end{array}$ & $\begin{array}{l}\text { Faster than } \\
\text { two previous } \\
\text { blockchain } \\
\text { networks }\end{array}$ & $\begin{array}{l}\text { Proof of } \\
\text { work and } \\
\text { proof of } \\
\text { stack }\end{array}$ & $\begin{array}{l}\text { Hyper- } \\
\text { ledger and } \\
\text { Quorum }\end{array}$ \\
\hline $\begin{array}{l}\text { Private } \\
\text { Blockchain }\end{array}$ & $\begin{array}{l}\text { Only the net- } \\
\text { work operator } \\
\text { can write on it }\end{array}$ & $\begin{array}{l}\text { Only authorized } \\
\text { participants are } \\
\text { allowed to read } \\
\text { the transactions } \\
\text { information on } \\
\text { the network }\end{array}$ & $\begin{array}{l}\text { There is a } \\
\text { network } \\
\text { owner }\end{array}$ & $\begin{array}{l}\text { Faster than } \\
\text { the first two } \\
\text { blockchain } \\
\text { networks }\end{array}$ & $\begin{array}{l}\text { Proof of } \\
\text { work and } \\
\text { proof of } \\
\text { stack }\end{array}$ & MultiChain \\
\hline
\end{tabular}

\section{Blockchain-based IPRs ecosystem}

As we mentioned earlier, the current IPRs system suffers from many technical, legal and financial problems. All these problems led to serious shortcomings effecting adversely the business environment and the innovation cycle. It could be argued here, that the current IPRs system lacks the efficiency and the flexibility required to respond to the market's changes.

For all the above reasons, using blockchain technology in the IPRs system would solve all these problems and increase the efficiency of innovation processes in the national economy. This technology will enable all stakeholders with entrepreneurial and unique ideas to convert them into inventions, or even individuals who have inventions and want to sell or exploit them commercially.

Advantages of the blockchain-based IP platform can be summarized as follows:

- Blockchain-based IP platform provides live data about patents and all other forms of intellectual property rights with easy searchability, since blockchain network stores all information about the IP objects that were registered on the platform. It also provides proof of existing and proof of ownership.

- By integrating some machine learning techniques and text mining into blockchain-based IP platform, inventors and investors will be able to find investment opportunities [12], since this platform represents a marketplace for inventions, patents and even novel ideas. These techniques allow participants on the platform to find the right invention/idea that meets the aspirations of investors in a specific area. Similarly, inventors will be able to find the financial resources needed for kick off their projects. This platform will allow market analysts to conduct a profound landscape of a particular technology to avoid duplication of other intellectual properties' ideas. Thus, this platform will make the research for similar IP objects more efficient, systematic and easier.

- Blockchain-based IP platform is a market for selling and buying various types of IP objects between inventors and investors. It helps in transferring the ownership of these objects, where each transaction on this platform is permanently stored and cannot be changed or manipulated. This preserves the right of all actors in this platform. 
- Blockchain-based IP platform will cut the costs significantly for all stakeholders (investors, inventors, and lawyers). Inventors will secure their ideas and IPRs. Investors will find good investment opportunities and they can buy IP objects. Lawyers will use the immutable information on this platform to proof the ownership and the existing of a particular IP object in the legal litigations. Thus, this platform brings together many services related to IPRs in one place.

Blockchain-based IP platform is considered a micro ecosystem of national IPRs system. This micro ecosystem can be generalized to the national level. Figure 2 represents the blockchain-based IPRs ecosystem. It consists of all stakeholders: inventors, investors, lawyers and government authority, all potential relationships among actors in this platform, and the work flow of this system.

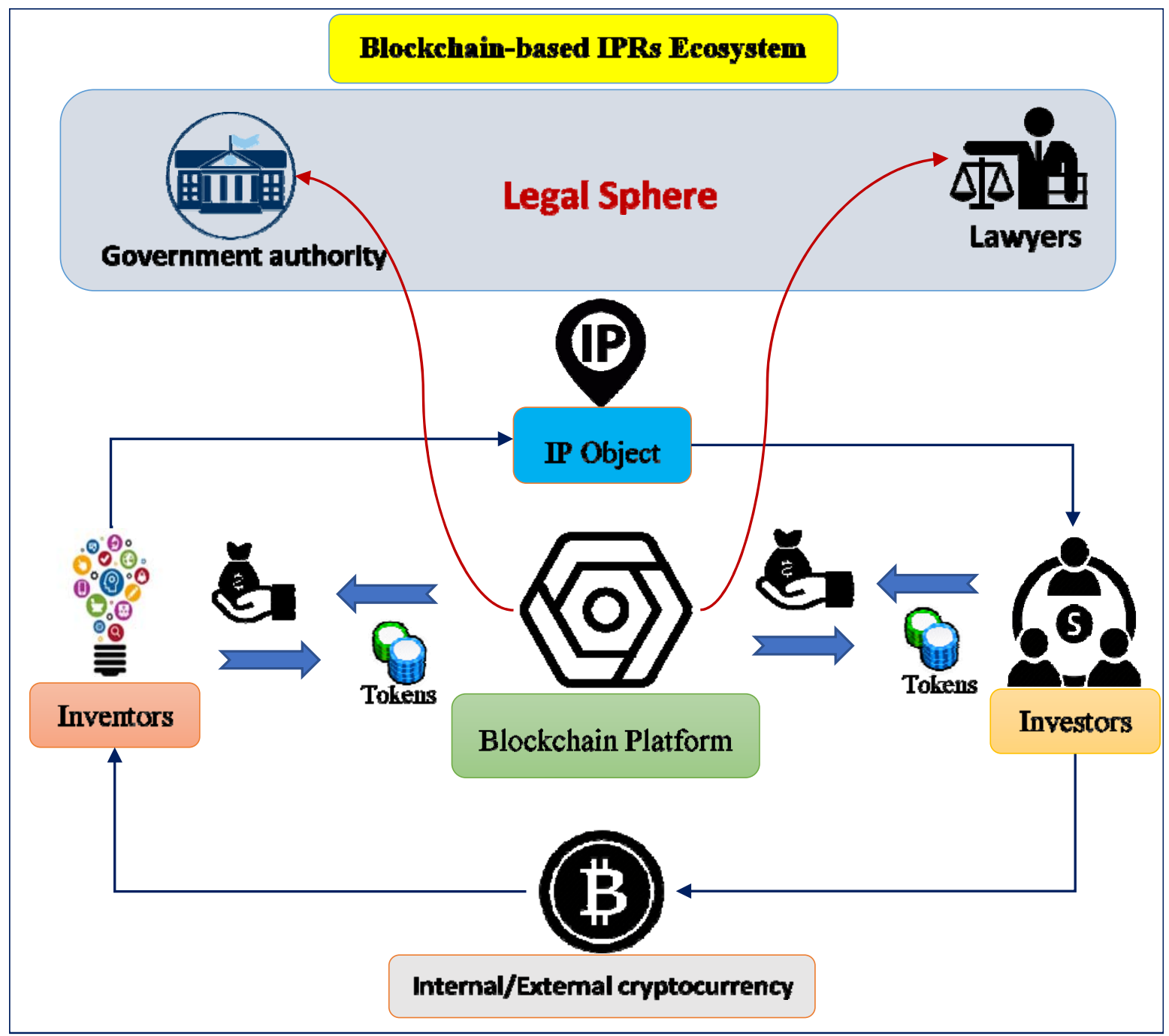

Fig. 2. Blockchain-based IPRs ecosystem

Regarding the work flow of this platform, it should be said that this platform links all stakeholders in the IPRs sphere, where they can interact (buy, sell, and transfer IP objects) through using the internal tokens of this platform. These tokens are considered an internal currency used to perform transactions within platform. They are exchangeable in the international cryptocurrencies market. Therefore, using tokens in this platform enables inventors commercializing their ideas and inventions. 
Despite all the previous advantages offered by this platform, the administration question remains an unsolved problem and needs to be overcome. What kind of blockchain network is best for managing this platform? Public permissioned or permissionedless, or private blockchain?

In this article, we argue that deploying blockchain technology within IPRs system at the national level, not just at the micro-level, improves the administrative capacity and the innovation competitiveness of the national economy, since generalization this kind of platform at the national level will enhance the efficiency of the national IPRs management system, which is a prerequisite for building a competitive national innovation system $[2 ; 18]$. Accordingly, we suggest creating a public permissioned blockchain platform in the first phase, where the government should be in charge. Taking in to account that the government is the only actor in the IP market that can set the regulatory standards of the IPRs related transactions. Otherwise, there will be many private companies managing many platforms, which, in this situation will make it hard to dispute resolution and legal enforcement [7]. When this platform reaches a high level of adoption and credibility at the national level, we suggest transforming it to a public permissionless network. At this stage, the network effect will ensure the sustainability, reliability and efficiency of the platform [1;9]. Thus, there is no longer a need for a third party to manage the IPRs related transactions, since the scalability of network was reached and the scale-effect has a positive impact on the way by which the blockchain-based IPRs platform works.

We suggest in this article that deploying blockchain technology within the national IPRs system needs to be done in two stages: (1) pre-registration stage and (2) post-registration stage.

In the pre-registration stage, the blockchain-based IPRs platform will be used to register all IP objects that have been registered in the national IP offices. Accordingly, they will be encrypted by blockchain technology and given public keys. Adding these IP objects to the blockchain-based IPRs network will empower and improve the quality of searching and text mining models integrated within the platform. So, by adding these IP objects to the network, we solve the problem of data availability needed to conduct a landscape of a particular market and explore the technological progress that have been done in this term.

In the post-registration stage, blockchain-based IPRs platform will be used to register new IP objects that have not been registered in the national offices. Here it is worth mentioning that this platform should be linked with the national IP offices in order to create a united national database of all intellectual properties that can be used as a reliable information in the national courts.

\section{Conclusion}

This article discussed the current obstacles facing the conventional IPRs system that associated basically with time, costs, security and reliability. In addition to the inhibitory role played by this conventional system in the innovation process at the national level.

In response to these problems, we suggested that deploying blockchain technology within the IPRs management system overcomes all shortcomings of the current system. The introduced approach to solve these problems is by building a blockchain-based IPRs platform brings together all stakeholders who are interested in IPRs: inventors, investors, lawyers and government authority.

We also argued that using this new technology for manging the IPRs system should be done at the national level, where the government should be responsible for administrating this platform. According to this suggestion, we argued that permissioned blockchain platform is an appropriate solution at the first stage. After that, we suggested that this permissioned blockchain platform should be transformed into permissionless one because of the network-effect and scalability advantages.

It worth noting that this platform can be improved by integrating various types of machine learning and text mining techniques, since these techniques can solve the problem of novelty checking when a new IP object would be registered on this platform. This issue is considered a crucial scope for other researchers to study in the future.

Finally, this paper tried to propose a new holistic approach for studying Blockchain-based IPRs ecosystem by presenting the current problems of the conventional IPRs system, proposing a solu- 
tion based on using blockchain technology, and drawing a map-road of this new IPRs management system.

\section{References}

1. Alabi, K. Digital blockchain networks appear to be following Metcalfe's Law. Electronic Commerce Research and Applications, 2017, vol. 24, p. 23-29. DOI 10.1016/J.ELERAP. 2017.06.003

2. Alnafrah I., Al Naimi K., Ahmad M. A comparative analysis of national innovation systems' structures and their developmental impacts (Evidences from BRICS countries). Scientific Journal NRU ITMO. Series: Economics and Environmental Management, 2018, no. 1 (32), p. 1320.

3. Dang J., Kang B., Ding K. International protection of standard essential patents. Technological Forecasting and Social Change. 2018. In press. DOI 10.1016/J.TECHFORE.2018.06.039

4. Efanov D., Roschin P. The All-Pervasiveness of the Blockchain Technology. Procedia Computer Science, 2018, no. 123, p.116-121.

5. Furukawa Y. Intellectual property protection and innovation: An inverted-U relationship. Economics Letters, 2010, vol. 109 (2), p. 99-101.

6. Glaeser S. The effects of proprietary information on corporate disclosure and transparency: Evidence from trade secrets. Journal of Accounting and Economics, 2018, vol. 66 (1), p. $163-$ 193. DOI 10.1016/J.JACCECO.2018.04.002

7. Goldenfein J., Leiter A. Legal Engineering on the Blockchain: 'Smart Contracts' as Legal Conduct. Law and Critique, 2018, vol. 29 (2), p. 141-149.

8. Hileman G., Rauchs M. Global Blockchain Benchmarking Study. Cambridge Centre for Alternative Finance, 2017. P. 1-122.

9. Lindman J., Tuunainen V. K., Rossi M. Opportunities and risks of Blockchain Technologies - a research agenda. 2017. URL: https://aisel.aisnet.org/cgi/viewcontent.cgi?article= 1203\&context=hicss-50 (accessed 04.12.2018)

10. Liu S. H., Liao H. L., Pi S. M., Hu J. W. Development of a Patent Retrieval and Analysis Platform - A hybrid approach. Expert systems with applications, 2011, vol. 38 (6), p. 7864 7868.

11. Mougayar W. The business blockchain: promise, practice, and application of the next Internet technology. John Wiley \& Sons, 2016.

12. Narland K., Müller-Bloch C., Beck R., Palmund S. Blockchain to Rule the Waves-Nascent Design Principles for Reducing Risk and Uncertainty in Decentralized Environments. ICIS. 2017. URL: https://aisel.aisnet.org/cgi/viewcontent.cgi?article=1323\&context=icis2017 (accessed 25.11.2018)

13. Nakamoto S. Bitcoin: A peer-to-peer electronic cash system. 2008. URL: https:// bitcoin.org/bitcoin.pdf (accessed 12.10.2018)

14. Savelyev A. Copyright in the blockchain era: Promises and challenges. Computer Law \& Security Review, 2018, vol. 34 (3), p. 550-561.

15. Sweet C. M., Maggio D. S. E. Do stronger intellectual property rights increase innovation? World Development, 2015, vol. 66, p. 665-677.

16. Tapscott D., Tapscott A. Realizing the Potential of Blockchain. A Multistakeholder Approach to the Stewardship of Blockchain and Cryptocurrencies. In: World Economic Forum White Paper, 2017, June.

17. WIPO. World Intellectual Property Indicators. 2017. URL: https://www.wipo.int/publications/ en/details.jsp?id=4234 $($ accessed 29.11.2018) 
18. Bogdanova E. L., Alnafrah I. Analysis impact structure of national innovation system factors on the development process in Russia. Izvestia of Volgograd State Technical University, 2017, vol. 15 (210), p. 19-25. (in Russ.)

\section{Information about the Authors / Сведения об авторе}

Alnafrah Ibrahim, PhD Researcher, Faculty of Technological Management and Innovation, Department of Intellectual Property and Innovation Management, ITMO University (49 Kronverksky Ave., St. Petersburg, 197101, Russian Federation)

Ибрагим Альнафра, аспирант, факультет технологического менеджмента и инноваций, Санкт-Петербургский национальный исследовательский университет информационных технологий, механики и оптики (Университет ИТМО) (Кронверкский проспект, 49, СанктПетербург, 197011, Россия)

ibrahimnafrah@gmail.com

ORCID 0000-0002-7448-8315

Researcher ID E-4606-2017

Elena L. Bogdanova, Professor, Doctor of Economics, Head of Center of Support of Intellectual Property, ITMO University (49 Kronverksky Ave., St. Petersburg, 197101, Russian Federation)

Богданова Елена Леонардовна, профессор, доктор экономических наук, директор Центра развития института интеллектуальной собственности, Санкт-Петербургский национальный исследовательский университет информационных технологий, механики и оптики (Университет ИТМО) (Кронверкский проспект, 49, Санкт-Петербург, 197011, Россия)

elbogdanova@corp.ifmo.ru

ORCID 0000-0002-8883-6181 